AL-IQTISHOD: Jurnal Pemikiran dan Penelitian Ekonomi Islam

E-ISSN: 2407-6600 P-ISSN: 2745-85I2

Volume I0 Issue I Januari 2022 | Page: 043-062

DOI: https://doi.org/I0.37812/aliqtishod

\title{
Peran Zakat Dalam Menanggulangi Kemiskinan
}

\author{
Dyah Suryani \\ Universitas Muhammadiyah Sidoarjo \\ dyahsuryani2323@gmail.com \\ Lailatul Fitriani \\ Universitas Muhammadiyah Sidoarjo \\ lailatulfitriani395@gmail.com
}

\begin{abstract}
Poverty is a problem that occurs in many countries, both developing and developed countries. As the third pillar of Islam after the creed and prayer, zakat is also a very important form of obligation for Muslims to respect others. Indonesia has regulated zakat management in the Zakat Management Act carried out by the National Amil Zakat Agency (BAZNAS) and the Amil Zakat Institution (LAZ). The research was conducted using a literature study method using a descriptive analysis approach, namely by looking at previous articles and published articles. The data analysis technique used is editing, organizing, finding. The very prominent role of zakat is to help other Muslim communities and unite their hearts so that they always hold fast to Islam and also help any problems that arise. The thing that must be done from the start is to overcome the poverty that surrounds the surrounding community by creating an economic order that allows the birth of a distribution system In a fair manner, zakat management strategies are all oriented towards multiplying the reward of muzakki and to improve the welfare of the mustahik and the zakat centralization system is also able to alleviate existing poverty.
\end{abstract}

Keywords: analysis, zakat, poverty

Abstrak: : Kemiskinan merupakan suatu masalah yang terjadi di berbagai negara baik negara berkembang ataupun negara maju. Sebagai rukun islam yang ketiga setelah syahadat dan shalat, zakat juga bentuk kewajiban yang sangat penting bagi umat islam untuk menghormati sesama. Indonesia telah mengatur pengelolaan zakat dalam Undang-Undang Pengelolaan Zakat yang dilakukan oleh Badan Amil Zakat Nasional (BAZNAS) dan Lembaga Amil Zakat (LAZ). Penelitian dilakukan dengan metode studi kepustakaan dengan menggunakan pendekatan analisis deskriptif yaitu dengan melihat dari artikel-artikel terdahulu dan artikel publikasi. Teknik analisis data yang digunakan editing, organizing, finding. Peran zakat yang sangat menonjol ialah membantu masyarakat muslim lainnya dan menyatukan hati agar selalu berpegang teguh terhadap islam dan juga membantu setiap permasalahan yang timbul Hal yang harus dilakukan sejak awal ialah mengatasi kemiskinan yang melilit masyarakat sekitar adalah dengan cara mewujudkan tatanan ekonomi yang memungkinkan lahirnya sistem distribusi yang adil, strategi pengelolaan zakat yang semuanya berorientasi pada berlipatgandanya pahala muzaki dan untuk meningkatkan kesejahteraan para mustahik dan sistem sentralisasi zakat juga mampu mengentaskan kemiskinan yang ada.

Kata Kunci: analisis, zakat, kemiskinan 



\section{A. Pendahuluan}

Kemiskinan merupakan suatu masalah yang terjadi di berbagai negara baik negara berkembang ataupun negara maju. Kemiskinan merupakan masalah yang mendasar dan menjadi pusat perhatian pemerintah di berbagai negara. Terdapat strategi yang mendukung dalam penanggulangan kemiskinan ialah tersedianya data kemiskinan yang akurat sehingga dapat memperoleh hasil pengukuran yang dapat dipercaya dan dapat dijadikan sebagai pengambilan kebijakan yang bertujuan untuk fokus dalam memperhatikan kondisi masyarakat miskin. Kegiatan ini dilakukan untuk mengevaluasi kebijakan pemerintah terkait kemiskinan dan dipergunakan untuk menentukan target masyarakat miskin yang bertujuan untuk memperbaiki kondisi kehidupan mereka ${ }^{\mathrm{P}}$.

Indonesia merupakan negara yang memiliki angka kemiskinan yang tinggi. Terjadinya Kemiskinan ini disebabkan oleh kurangnya masyarakat untuk mendapatkan modal dan tidak adanya lapangan pekerjaan yang memadai. Oleh karena itu penyebab ini menjadikan sulitnya penurunan angka kemiskinan di Indonesia ${ }^{2}$. Penduduk miskin di Indonesia dalam tiga tahun terakhir yang dikelompokkan indeks per-bulan dimulai pada bulan Maret September 2018 memiliki penurunan sebesar 0.16\%, bulan Maret - September 2019 memiliki penurunan sebesar 0.19\%, sedangkan bulan Maret - September 2020 memiliki peningkatan sebesar $0.41 \%$. Maka apabila dikelompokkan indeks pertahun mulai 20182020 kemiskinan di Indonesia mengalami peningkatan yang cukup tinggi. Hal ini berdasarkan analisa data dalam diagram sebagai berikut :

\footnotetext{
I Nur Amalia, "Peranan Baznas Dalam Menanggulangi Kemiskinan Di Kota Makassar” (2020).

2 Yoghi Citra Pratama, "Peran Zakat Dalam Penanggulangan Kemiskinan (Studi Kasus: Program Zakat Produktif Pada Badan Amil Zakat Nasional) [The Role Of Zakat In Poverty Alleviation (Case Study: Productive Zakat Program At The National Amil Zakat Board)],” The Journal Of Tauhidinomics I, No. I (2015): 93-I04.
}

Volume. I0/No. I/Januari 2022 Al-Iqtishod | 43 


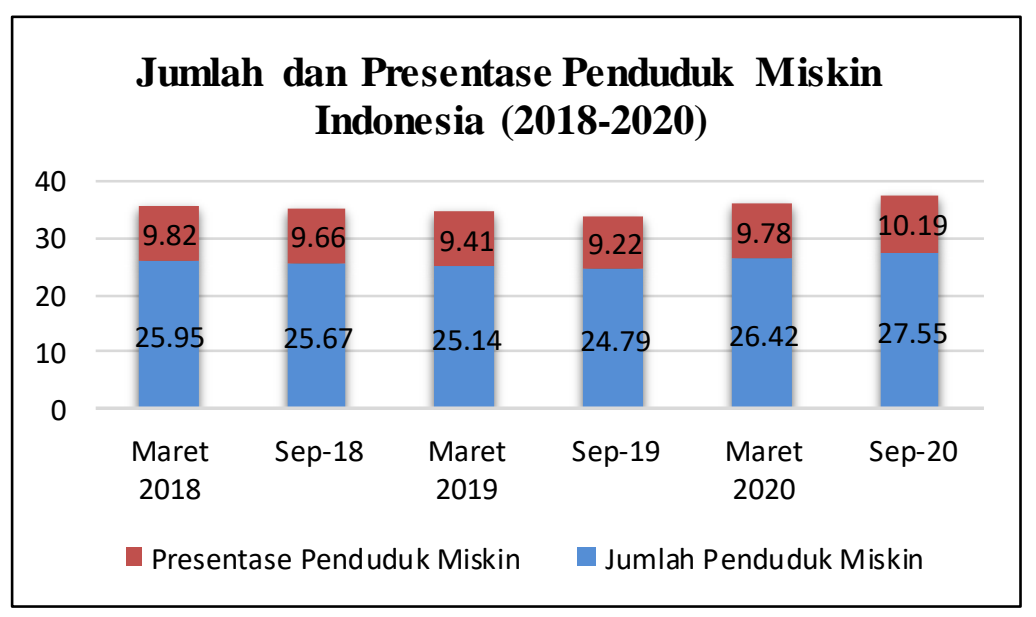

Gambar I. Jumlah dan Presentase Penduduk Miskin Indonesia (2018-2020)

Sumber : Badan Pusat Statistik, 2020 3 .

Kemiskinan merupakan suatu yang berbahaya bagi manusia karena dapat merusak akidah, akhlak, fikiran, dan keluarga. Maka dalam hal ini kemiskinan harus mendapatkan solusi melalui kebijakan fiskal yakni berupa zakat ${ }^{4}$. Agama islam memiliki cara untuk memperhatikan dan mengatasi kemiskinan sehingga orang-orang miskin dan kaum dhuafa terbebas dalam kemiskinan. Dalam hal ini harus konsisten karena islam mempunyai konsep untuk mengentaskan kemiskinan dan membangun aturan sosial dengan saling tolong menolong. Konsep yang dimaksud adalah orang kaya sebaiknya menysisikan harta kecilnya untuk diberikan kepada orang miskin dan golongan yang kurang mampu. Pemberian ini berupa zakat, infaq, dan shadaqah.

Setiap muslim yang mampu maka harus memenuhi kewajiban yang ditentukan syariat islam dengan mengeluarkan zakat sebagaimana menyempurnakan rukun islam yang keempat . Zakat mempunyai potensi yang efektif sebagai sarana dalam memberdayakan ekonomi umat sehingga zakat diharapkan memiliki peran untuk mengentaskan kemiskikan, menanggulangi kemiskinan yang dilakukan kepada orang miskin terutama yang

\footnotetext{
3 (Badan Pusat Statistik, 2020)

${ }^{4}$ Qardhawi, Spektrum Zakat Dalam Membangun Ekonomi Kerakyatan (Jakarta: Zikrul Hakim, 2005).
} 
membutuhkan perhatian dari semua pihak. ${ }^{5}$ Zakat dapat dikembangkan melalui pembiayaan modal usaha dan pendayagunaan masyarakat miskin yang bertujuan agar masyarakat dapat mempunyai modal dan pengalaman sehingga dapat berguna untuk menjadikan kehidupan lebih baik ${ }^{6}$.

Perkembangan zakat di Indonesia mengalami peningkatan pada tiga tahun terakhir yakni pada tahun 2017, 2018, 2019. Pada tahun 2017-2018 dana zakat Nasional mengalami peningkatan sebesar $14,5 \%$. Pada tahun 2018-2019 dana zakat Nasional mengalami peningkatan sebesar I5\%. Dalam hal ini terdapat pada analisa data dalam diagram sebagai berikut :

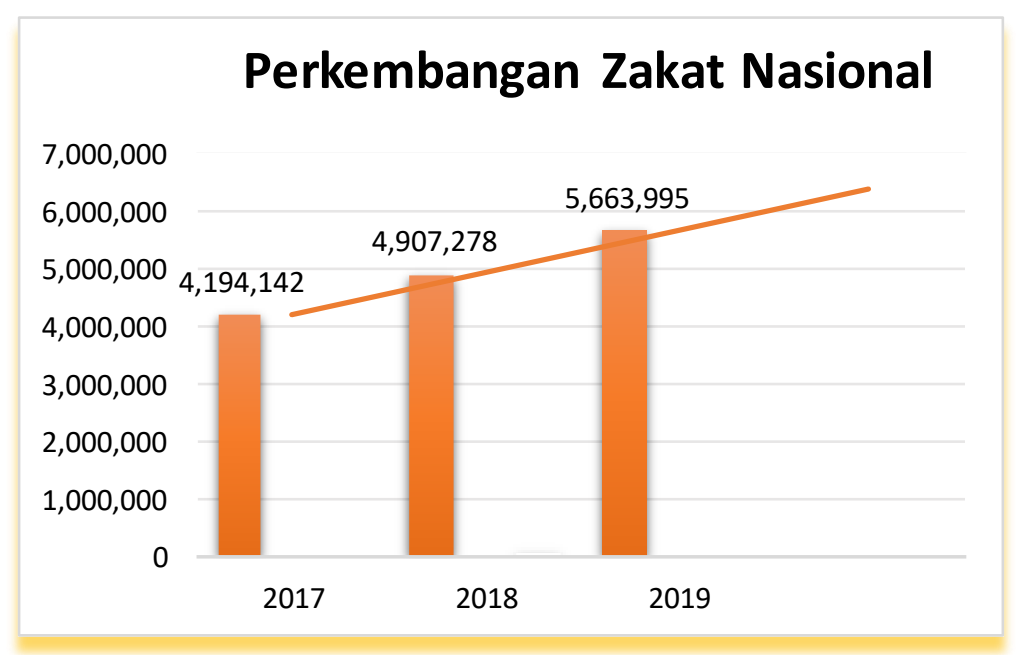

Gambar 2. Perkembangan Zakat Nasional (2017-2019)

Sumber : Badan Amil Zakat Nasional 7.

Instrument zakat dipergunakan untuk menyeimbangkan pendapatan masyarakat. Zakat yang dikeluarkan merupakan salah satu bentuk distribusi pendapatan agar lebih merata sehingga orang fakir maupun miskin dapat melaksanakan kewajibannya kepada Allah. Zakat dalam bidang ekonomi mempunyai peran untuk mencegah penumpukan

\footnotetext{
${ }^{5}$ Muhammad Kambali and Fatur Rahman, "Pengaruh Aplikasi Muzakki Corner Terhadap Minat Mayarakat Berzakat” I0, no. 2 (202I): I75-I84.

${ }^{6}$ Amalia and Kasyful Mahalli, "Analisis Peran Zakat Dalam Mengurangi Kemiskinan: Studi Kasus Dompet Dhuafa Republika,” Jurnal Ekonomi Dan Keuangan, 2012.

${ }^{7}$ Badan Amil Zakat Nasional, Statistik Zakat Nasional 20I7-2019, n.d.
}

Volume. I0/No. I/Januari 2022 Al-Iqtishod | 45 
Peran Zakat dalam.....

kekayaan dan mewajibkan orang kaya agar menyalurkan hartanya kepada golongan yang kurang mampu, maka zakat memiliki fungsi sebaga sumber dana untuk mengentaskan kemiskinan dan sebagai modal kerja bagi orang miskin agar dapat membuka lapangan pekerjaan dan mendapatkan penghasilan yang digunakan untuk memenuhi kebutuhan sehari-hari ${ }^{8}$.

Penelitian Zakat dalam menanggulangi kemiskinan sudah banyak dilakukan di Indonesia sehingga banyak peneliti yang memberikan statemen bahwa zakat memang salah satu cara untuk membebaskan masyarakat dari kemiskinan serta dapat memberikan kekuatan dalam bidang ekonomi. Agar peneliti dapat memberikan pernyataan yang relevan dan dapat diketahui perbandingannya maka terdapat kajian dari penelitian terdahulu, antara lain :

Pertama, penelitian dari Irfan Syauqi Beik dengan judul "Zakat \& Empowering Analisis Peran Zakat dalam Mengurangi Kemiskinan : Studi Kasus Dompet Dhuafa Republika” pada penelitiannya menyimpulkan bahwa kemisikinan merupakan masal;ah terbesar yang dihadapi oleh negara Indonesia. Maka pemerintah Indonesia dapat memberikan kebijakan untuk mengatasi permasalahan tersebut. Dalam hal ini terdapat suatu solusi alternative yakni memanfaatkan dan mengoptimalisasikan zakat yang dikembangkan dalam lembaga dompet dhuafa republika yang bertujuan untuk mengurangi tingkat kemisikinan dalam sistem mendayagunakan zakat yang secara ilmiah bersifat empiris ${ }^{9}$.

Kedua, penelitian dari Nurwati dan Heni Hendrawati yang berjudul "Zakat dan Upaya Mengentaskan Kemiskinan" dalam penelitian ini menyimpulkan bahwa mendayagunaan zakat merupakan sebuah kontribusi yang dapat mendukung pemerintah dalam mengentaskan kemiskinan. Zakat fokus disalurkan kepada fakir dan miskin dalam bidang sosial kemanusiaan dan pendidikan sehingga dapat mengoptimalisaikan kesejahteraan dalam bidang ekonomi di Indonesia. Pemerintah telah memberikan

\footnotetext{
${ }^{8}$ Rozalinda, Ekonomi Islam: Teori Dan Aplikasinya Pada Aktivitas Ekonomi (Jakarta: Rajagrafindo, 20I4).

9 Irfan Syauqi Beik, "Analisis Peran Zakat Dalam Mengurangi Kemiskinan: Studi Kasus Dompet Dhuafa Republika,” Pemikiran Dan Gagasan 2, no. January 2009 (2009): 45-53.
} 
komitmen yang besar dalam permasalahan ini. Dengan adanya partisipasi masyarakat terutama umat islam menjadi faktor pendukung yang sangat penting dalam mencapai citacita tersebut ${ }^{10}$.

Ketiga, penelitian dari Abdul Haris Romdhoni yang berjudul "Zakat Dalam Mendorong Pertumbuhan Ekonomi Dan Pengentasan Kemiskinan” dalam penelitian ini menyimpulkan bahwa zakat produktif sangat berpengaruh pada meningkatknya pendapatan mustahik yang menerima program zakat serta dapat memberikan pengaruh positif. Zakat produktif ini merupakan program pemberdayaan di LAZ An-Naafi' Boyolali yang bertujuan untuk meningkatkan penghasilan dan para mustahik agar dapat membuka usaha dari penghasilan yang diterima. Dalam penelitian ini telah dibenarkan kepada salah satu mustahik bahwa mereka mendapatkan penghasilan tambahan yang digunakan untuk modal produktif ${ }^{11}$.

Berdasarkan analisa latar belakang dan analisa kajian penelitan terdahulu, maka penelitian ini terfokus pada rumusan masalah diambil yaitu bagaimana pengelolaan zakat di Indonesia dan bagaimana peranan zakat dalam menanggulangi kemiskinan di Indonesia.

\section{B. Kajian Pustaka}

\section{Zakat}

Zakat merupakan salah satu pilar yang sangat penting dalam Islam. Secara etimologis, zakat artinya berkembang (an-namaa), mensucikan (at-thaharatul) dan berkah (albarakatu). Sedangkan secara terminologis, zakat berarti mengeluarkan sebagian harta dengan persyaratan tertentu untuk diberikan kepada kelompok tertentu (mustahik) dengan persyaratan yang tertentu juga ${ }^{\mathrm{I}}$. Sedangkan zakat dalam pengertian berkah adalah sisa harta yang telah dikeluarkan zakatnya secara

\footnotetext{
I0 Nurwati and Heni Hendrawati, "Zakat Dan Upaya Mengentaskan Kemiskinan,” Cakrawala: Jurnal Studi Islam I4, no. I (2019): 40-47, https://doi.org/I0.3I603/cakrawala.vI4iI.2695.

II Abdul Haris Romdhoni, "Zakat Dalam Mendorong Pertumbuhan Ekonomi Dan Pengentasan Kemiskinan,” Jurnal Ilmiah Ekonomi Islam 3, no. I (2017), https://doi.org/I0.31538/adlh.v3iI.403.

${ }^{12}$ Hafidhuddin D, Zakat Dalam Perekonomian Modern (Jakarta: Gema Insani Press, 2002).
}

Volume. IO/No. I/Januari 2022 Al-Iqtishod | 47 
kualitatif dan mendapatkan berkah dan akan berkembang meskipun secara kuantitatif jumlahnya telah menyusut ${ }^{13}$.

Sementara itu Al-Qhardhawi (2002) juga mengatakan bahwa tujuan mendasar dari ibadah zakat ialah untuk menyelesaikan berbagai macam persoalan sosial seperti pengangguran, kemiskinan, dll. Sistem distribusi zakat adalah solusi yang sesuai mengenai masalah tersebut dengan memberikan bantuan kepada orangorang yang kesulitan tanpa memandang ras, warna kulit, etnis, d11 ${ }^{14}$. Dalam AlQur'an Allah berfirman ,

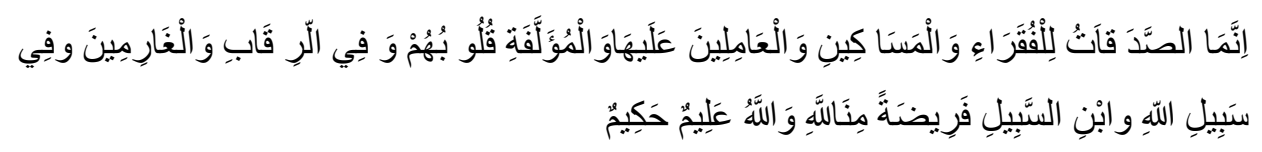

Artinya :

"Ambillah zakat dari sebagian harta mereka, dengan zakat itu kamu membersihkan dan mensucikan mereka dan mendo'a lah untuk mereka. Sesungguhnya do’a kamu itu (menjadi) ketenteraman jïwa bagi mereka. Dan Allah Maha Mendengar lagi Maha Mengetahui”(QS. Al-Taubah : 60)

Sebagai rukun islam yang ketiga setelah syahadat dan shalat, zakat juga bentuk kewajiban yang sangat penting bagi umat islam untuk menghormati sesama. Zakat pun diartikan sebagai hitungan tertentu dari harta dan sejenisnya dimana syarat diwajibkannya mengeluarkan hartanya kepada pada fakir, dan sejenisnya dengan syarat-syarat khusus ${ }^{15}$, pengertian zakat sering sekali disinggung didalam AlQur'an maupun hadist Nabi saw, terdapat dalam ayat berikut :

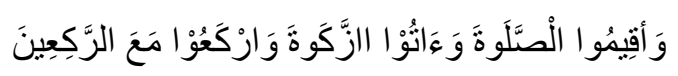

Artinya :

"dan dirikanlah shalat,tunaikanlah zakat dan ruku'lah beserta orang-orang yang ruku' "(QS. Al-Baqarah : 43)

\footnotetext{
${ }^{13}$ Ahmad Atabik, "Peranan Zakat Dalam Pengentasan Kemiskinan," ZISWAF: Jurnal Zakat Dan Wakaf 2, no. 2 (2015): 339-6I.

${ }^{\text {I4 }}$ Al-Qardawi, Zakat Role in Curing Social and Economic Malaises, Economics of Zakat, Kahf (Jeddah: IRTI-IDB, 2002).

${ }^{15}$ Atabik, "Peranan Zakat Dalam Pengentasan Kemiskinan."
}

48| Al-Iqtishod Volume. IO/No. I/Januari 2022 


\section{Kemiskinan}

Suatu ketimpangan sosial dalam hal kekayaan menjadi masalah yang sering dihadapi oleh seluruh Negara, mulai dari daerah yang maju hingga daerah yang miskin. Kemiskinan dapat dilihat dari dua sisi yaitu :

a. Kemiskinan absolut, hal tersebut dapat diidentifikasikan pada berapa banyak penduduk yang hidup dibawah garis kemiskinan

b. Kemiskinan relatif, dilihat dari pendapatan nasional yang diterima oleh masing-masing golongan pendapatan. Artinya kemiskinan relatif memiliki keterkaitan dengan permasalahan distribusi pendapatan ${ }^{16}$

Islam memiliki sudut pandang mengenai kemiskinan antara lain :

a. Miskin secara iman, artinya seseorang yang ruhnya tidak dekat dengan Allah, ia hanya mendekat kepada Allah swt hanya bila mendapatkan musibah saja.

b. Miskin berdasarkan ilmu, salah satu menjadi penyebab seseorang mengalami kemiskinan ialah karena ketidaktahuan bagaimana menemukan penyelesaian permasalahan didalam hidupnya.

c. Miskin secara harta, artinya bahwa seseorang memiliki kemampuan untuk dapat bekerja dan berusaha dengan tujuan memperoleh suatu kekayaan untuk menghidupi keluarganya dan bertahan hidup secara halal, namun penghasilan yang diperolehnya masih belum memenuhi segala kebutuhan dirinya sendiri dan keluarganya ${ }^{17}$

\section{Metode Penelitian}

Metode dalam penelitian ini menggunakan metode studi kepustakaan (library research) dengan menggunakan pendekatan analisis deskriptif. Studi kepustakaan merupakan sebuah riset kepustakaan dengan mengumpulkan data pustaka, membaca

\footnotetext{
${ }^{16}$ Gunawan Sumodiningrat, "Kemiskinan : Teori, Fakta Dan Kebijakan,” I999.

17 "Jurnal Ekbisi Fakultas Syariah,” Jurnal Ekbisi Fakultas Syariah UIN Sunan Kalijaga Yogyakarta 5, no. I (2010).
}

Volume. I0/No. I/Januari 2022 Al-Iqtishod | 49 
data pustaka, serta mencatat dan mengolah data pustaka yang berkaitan dengan objek penelitian ${ }^{18}$. Pendekatan analisis deskriptif adalah sebuah cara yang digunakan untuk menganalisis data dengan mendeskripsikan data yang telah dikumpulkan sehingga dapat ditarik kesimpulan ${ }^{19}$.

Peneliti mengumpulkan data dari membaca refrensi kepustakaan yang diperoleh dari jurnal, artikel, website, buku-buku yang terdapat dalam google scholar, moraref dan website resmi badan pusat statistik yang berkaitan dengan objek penelitian. Dalam hal ini peneliti menggunakan sumber data yaitu data sekunder yang merupakan data tambahan yang diperoleh dari refrensi kepustakaan yang berperan sebagai pendukung dan penguat konsep yang ada dalam buku, jurnal, artikel, website resmi badan pusat statistik.

Teknik analisis data yang digunakan adalah pertama editing yakni peneliti memeriksa kembali data yang telah dikumpulkan dan diperoleh dengan menyesuaikan makna yang jelas antara data satu dengan data yang lain. Kedua, organizing (pengelompokkan data) yakni peneliti mengolah data yang diperoleh dengan menyesuaikan kerangka-kerangka yang telah ditentukan. Ketiga, finding yakni peneliti menganalisis hasil organizing data dengan menerapkan teori-teori dan metode yang telah ditentukan dan dapat ditarik kesimpulan sehingga mendapatkan jawaban dari rumusan masalah ${ }^{20}$.

\section{Hasil dan Pembahasan}

\section{Pengelolaan Zakat di Indonesia}

Pada masa Rasulullah SAW kegiatan zakat telah dilaksanakan dan merupakan suatu kegiatan yang wajib bagi umat muslim yang menjadi salah satu bentuk keimanan dalam membangun agama dan memperbaiki kondisi ekonomi sesuai

\footnotetext{
${ }^{18}$ Mestika Zed, Metode Penelitian Kepustakaan (Jakarta: Yayasan Pustaka Obor Indonesia, 2014).

${ }^{19}$ Sugiyono, Metode Penelitian Kuantitatif, Kualitatif, Dan R\&D (Bandung: Alfabeta, 2013).

20 R. Poppy Yanjawati, "Penelitian Studi Kepustakaan (Library Research)" (Disajikan Pada Acara "Penyamaan Persepsi Penelitian Studi Kepustakaan” Di Lingkungan Dosen Fkip Unhas, 2020).
} 
syariat islam. Pada zaman khulafaur rasyidin, zakat berperan sebagai pendapatan utama dalam suatu negara Islam dan menjadi tolak ukur aspek fiskal yang bertujuan untuk memperbaiki masalah dalam bidang ekonomi secara universal sehingga apabila zakat tidak dilaksanakan sesuai kewajiban maka dikenakan denda sebesar 50\%, denda ini diberlakukan kepada setiap muslim yang tidak mengeluarkan hartanya untuk berzakat. Dalam hal ini zakat memiliki peran yang sangat penting untuk kemaslahatan umat islam.

Zakat merupakan instrument dalam ekonomi islam yang dapat memberikan pengaruh terhadap tingkah laku seorang muslim dan dapat membangun ekonomi. Dalam awal sejarah islam, zakat berperan sebagai sumber pendapatan negara terbesar dibandingkan sumber pendapatan yang lain seperti ghanimah, kharaj, fai, jizyah. Apabila zakat dikelola secara efektif dan efisien maka dapat bermanfaat bagi masyarakat miskin yang berhak mendapatkan haknya untuk memenuhi kebutuhan primer. Maka hal ini zakat telah berhasil menjadi instrumen yang dapat melepaskan masyarakat dari kemiskinan dan dapat menjadi solusi pemerataan ekonomi masyarakat miskin serta mendorong pembangunan ekonomi bangsa ${ }^{21}$.

Pendapatan utama di Indonesia diperoleh dari pembayaran pajak. Dalam hal ini Indonesia menerapkan kewajiban zakat melalui Undang-Undang Pengelolaan Zakat. Zakat merupakan suatu kewajiban untuk mengeluarkan harta oleh umat islam atau badan usaha agar diberikan kepada pihak yang berhak menerima zakat dan sesuai dengan ketentuan syariat islam. Dalam berzakat, maka terdapat suatu harta yang memiliki kewajiban untuk dizakati yaitu, perak, emas, uang, surat berharga, pendapatan seseorang dari pekerjaan apapun yang mencapai nisab, rikaz ${ }^{22}$.

Indonesia telah mengatur pengelolaan zakat dalam Undang-Undang Pengelolaan Zakat yang dilakukan oleh Badan Amil Zakat Nasional (BAZNAS)

21 Muslih Aris, "Eksistensi Nilai Al 'Adalah Pada Kebijakan Zakat Di Indonesia," Al-Iqtishod: Jurnal Pemikiran Dan Penelitian Ekonomi Islam 9, No. I (202I).

${ }^{22}$ Indah Purbasari, "Pengelolaan Zakat Oleh Badan Dan Lembaga Amil Zakat Di Surabaya Dan Gresik," Mimbar Hukum 27, No. I (2015): 68-8I.

Volume. IO/No. I/Januari 2022 A1-Iqtishod | 5 I 
dan Lembaga Amil Zakat (LAZ). BAZNAS merupakan suatu badan hukum yang berperan dalam mengelolah zakat dan dibentuk oleh pemerintah yang berkedudukan di Kabupaten atau Kota dan Provinsi. Segmen pembayaran zakat di BAZNAS yaitu, Pegawai Negeri Sipil (PNS) dalam lingkungan Kabupaten atau Kota, Pejabat, dan Birokrat. BAZNAS juga menerima pembayaran zakat dari masyarakat umum. LAZ merupakan lembaga yang berperan dalam mengelolah zakat yang dibentuk oleh pemikiran masyarakat atau badan hukum sendiri yang diresmikan oleh pemerintah. Dengan adanya badan hukum atau lembaga zakat maka diharapkan dapat menerapkan pengelolaan zakat yang sesuai dengan ketentuan perundang-undangan yang pembentukan berdasarkan wilayah Kecamatan, Kabupaten atau Kota, Provinsi ${ }^{23}$.

Berdirinya lembaga pengelola zakat sangat penting karena mayoritas penduduk Indonesia beragama islam sehingga potensi zakat sangat besar. Masyarat Indonesia terutama beragama islam sebagian juga minim terhadap kesadaran membayar zakat dikarenakan terdapat ketidakpercayaan kepada BAZNAS yang merupakan badan pengelolaan zakat yang berkaitan dengan rendahnya tatakelola pemerintahan yang bersih. Lembaga-lembaga pengelola zakat harus mampu menjalankan fungsinya yakni sebagai amil zakat. Amil zakat berfungsi sebagai sasaran dalam zakat, dapat merencanakan zakat untuk kedepannya, menghimpun dana zakat dari orang-orang yang wajib membayar zakat, dapat melaksanakan pengelolaan zakat, melakukan pengawasan dalam pengelolaan zakat. Amil zakat dalam mengelola zakat harus mempunyai sifat yang amanah, professional, dan transparan yang harus diterapkan dalam kinerja penghimpunan dan penyaluran zakat yang sebagai bentuk wujud kepercayaan masyarakat menyalurkan hartanya ${ }^{24}$.

\section{a. Penghimpunan Dana Zakat}

23 "Undang-Undang Nomor 23 Tahun 201 I Tentang Pengelolaan Zakat (Lembaran Negara Republik Indonesia Tahun 201 I Nomor II5).

${ }^{24}$ Rika Rahmadina Putri, "Strategi Penyaluran Dana Zakat, Infaq Dan Shadaqah (Studi Kasus Baznas Kota Prabumulih)," Adl Islamic Economic 2, No. I (202I). 
Terdapat beberapa tahap dalam menghimpun dana zakat, antara lain ${ }^{25}$ :

I. Menganalisis profil donatur

Dalam melakukan penghimpunan zakat maka lembaga zakat yang harus mengetahui profil donatur dengan memberikan formulir registrasi muzaki, mengajukan beberapa pertanyaan kepada donatur, melengkapi identitas yang menjadi persyaratan yakni NIK, KTP, alamat, nomer handphone, nomer rekening dan atas nama rekening. Data-data donatur diserahkan kepada BAZNAS pusat sebagai bentuk database lembaga yang bertujuan untuk melaporkan dana zakat yang telah disalurkan dan untuk memberikan informasi undangan jika terdapat kegiatan yang berkaitan dengan muzaki.

2. Promosi dan bersosialiasi

Dalam melakukan penghimpunan dana zakat, maka BAZNAS harus melakukan sosialisasi kepada masyarakat tentang pentingnya berzakat, dalam hal ini menggunakan metode fundraising yakni metode tidak langsung. Promosi dilakukan dengan memasang iklan di media elektronik seperti televise dan radio, memasang iklan di media massa, dan memasang baliho, sedangkan sosialiasi yang dilakukan yakni mengadakan webinar, bersilahturahmi kepada perusahaan besar, bersosialiasi kepada masyarakat dalam acara religi.

3. Layanan tranksaksi

Dalam melakukan penghimpunan dana zakat terdapat suatu alat transaksi yang digunakan untuk membayar zakat. Teknik layanan transaksi dapat dilakukan melalui non tunai dan tunai. Transaksi non tunai atau online dapat dilakukan melalui ATM, mobile banking yang terdapat fasilitas

${ }^{25}$ Abdul Azis And Ating Sukma, "Strategi Penghimpunan Dana Zakat Lima Lembaga Pengelola Zakat Di Indonesia," Jurnal Syarikah: Jurnal Ekonomi Islam 2, No. I (2016): I3I-48, Https://Doi.Org/I0.30997/Jsei.V2iI.269.

Volume. IO/No. I/Januari 2022 Al-Iqtishod | 53 
pembayaran zakat, aplikasi muzaki corner dan jemput zakat, apabila tunai dapat dilakukan dengan mendatangi kantor BAZNAS secara langsung.

4. Pelayanan donatur

Dalam melakukan pengghimpunan zakat, terdapat suatu strategi dalam melayani donatur. pelayanan donatur dilakukan dengan memberikan laporan bulanan yang berbentuk majalah yang dipergunakan untuk mengingatkan agar melakukan zakat dalam satu bulan sekali. Terdapat pelayanan donatur potensial yakni dilakukan dengan bersilaturahmu kepada donatur untuk mengundang donatur dalam acara yang diselenggarakan BAZNAS.

\section{b. Penyaluran Dana Zakat}

Dalam penyaluran dana zakat, terdapat dua strategi dalam menyalurkan, antara lain ${ }^{26}$ :

I. Penyaluran dana zakat secara langsung

Penyaluran ini dilakukan langsung kepada mustahik atau mendatangi kantor BAZNAS.

2. Penyaluran zakat secara tidak langsung

Penyaluran ini dilakukan oleh lembaga atau mitra yang diserahkan kepada unit saluran zakat setempat atau dapat diserahkan di LAZ.

Dalam penyaluran dana zakat, terdapat 8 golongan yang berhak mendapatkan dana zakat, antara lain ${ }^{27}$ :

I. Orang-orang fakir, yakni golongan yang menderita dalam kehidupannya, golongan ini tidak mempunyai harta sehingga tidak memiliki kemampuan untuk memenuhi kebutuhannya. Dana zakat diberikan untuk memenuhi tujuan produktif yang berupa hibah dan pinjaman tanpa bunga dengan tujuan dapat lepas dari masalah kemiskinan.

${ }^{26}$ Syaipudin Elman, "Strategi Penyaluran Dana Zakat Baznas Melalui Program Pemberdayaan Ekonomi," Uin Syarif Hidayatullah (20I5), Https://Doi.Org/I0.I I45/3I32847.3132886.

${ }^{27}$ Ahmad Atabik, "Peranan Zakat Dalam Pengentasan Kemiskinan," Ziswaf: Jurnal Zakat Dan Wakaf 2, No. 2 (20I5): 339-6I. 
2. Orang-orang miskin, yakni orang yang mampu dalam memperoleh pekerjaannya namun tidak mampu memenuhi kebutuhan hidupnya. Dana zakat yang diberikan dipergunakan untuk kebutuhan konsumtif yang sifatnya dalam jangka pendek.

3. Amil zakat, yakni orang-orang yang diberikan amanah dalam mengumpulkan dan mengelola dana zakat. Meskipun amil zakat memiliki kehidupan yang mampu dalam segi materi, mereka berhak memperoleh dana zakat. Dana zakat diberikan kepada amil zakat diharapkan dapat berkembang dan memotivasi agar lembaga zakat yang dikelola dapat maju dalam segi organisasi.

4. Muallaf, yakni orang non islam yang baru masuk islam yang memiliki keimanan lemah.

5. Budak, yakni orang-orang muslim yang menjadi tawanan orang kafir dalam beperang.

6. Orang yang berhutang, yakni termasuk hutang yang dipergunakan untuk memenuhi kebutuhan hidup, bukan hutang yang dipergunakan untuk maksiat dan tidak mampu untuk membayar.

7. Orang yang berperang dijalan Allah, yakni orang-orang yang mempertahankan agama islam dan kaum muslim. Pada zaman sekarang termasuk golongan orang-orang yang menyebarluaskan agama islam seperti para ulama atau kyai, ta'mir, dan yang berkaitan dengan dakwah agama islam.

8. Ibnu sabil, yakni orang-orang yang dalam perjalanan bukan untuk bermaksiat, melainkan orang dalam perjalanan yang mengalami kesengsaraan.

Macam-macam bentuk penyaluran dana zakat, antara lain ${ }^{28}$ :

${ }^{28}$ Ahmad Atabik, "Peranan Zakat Dalam Pengentasan Kemiskinan," Ziswaf: Jurnal Zakat Dan Wakaf 2, No. 2 (2015): 339-6I.

Volume. IO/No. I/Januari 2022 Al-Iqtishod | 55 
I. Bantuan kesehatan

Penyaluran di bidang kesehatan ini memberikan pelayanan kesehatan gratis kepada masyarakat, memberikan bimbingan yang berkaitan dengan kesehatan dan memberikan bantuan biaya rumah sakit. Dalam pelayanan ini terdapat unit kesehatan keliling dengan ambulance milik BAZNAS melakukan kunjungan di tiap-tiap daerah yang dilakukan pada tiap bulan.

2. Bantuan kemanusiaan

Penyaluran ini merupakan program yang dapat membantu masyarakat yang tertimpah musibah. Penyaluran ini berupa kebutuhan pokok seperti sembako dan obat-obatan.

3. Bantuan pendidikan

Penyaluran ini diberikan melalui program beasiswa bagi pelajar yang tidak mampu. Mulai dari tingkat SD, SMP, SMA, hingga ke perguruan tinggi. Bantuan ini bekerja sama dengan yayasan atau lembaga lainnya.

4. Bantuan ekonomi

Penyaluran ini diberikan sebagai bentuk mengembangkan ekonomi masyarakat miskin, dalam ini terdapat tiga cara, antara lain :

a) Pemberian modal kerja

b) Pemberian pembiayaan oleh Badan Mat Tamwil dibawah naungan BAZNAS

c) Pemberian sarana kerja

5. Masyarakat mandiri

Penyaluran ini merupakan program dalam bidang meningkatkan kualitas sumber daya manusia melalui pelatihan dan kerja sama dengan lembaga yang lainnya.

\section{Peranan Zakat dalam Menanggulangi Kemiskinan}

Di Indonesia, islam menyebar diberbagai daerah maupun desa terpencil. Umat islam yang bertempat tinggal dikota sebagian besar bermata pencaharian sebagai 
pegawai swasta atau pengusaha, sedangkan yang berada didesa mayoritas hanya sebagai buruh pabrik dan petani. Kondisi seperti ini biasanya diakibatkan beberapa faktor :

a. Faktor penduduk yang semakin lama semakin meningkat, sementara sektor pertanian tidak meningkat. Para pemilik modal semakin memperparah keadaan seperti sawah yang dipinggir jalan raya dibeli untuk dijadikan pabrik atau gedung bisnis lainnya. Hal ini mengurangi sawah dan tegal yang ada.

b. Belum berlakunya hukum tanah secara islam. Barang siapa yang memiliki tanah maka ia harus kerjakan dan tanami, jika tidak mampu mengerjakan maka seharusnya ia berikan untuk dikelola oleh orang lain atau tetangga maupun saudaranya

c. Petani miskin sudah tidak sanggup lagi mengerjakan sawah yang ia punya, sebab biaya produksi dan biaya pengelolahan yang mahal

d. Petani di Indonesia ternyata masih kurang mendapatkan investasi modal yang leluasa, bahkan masih ada saja para petani yang mengurus kredit ke Bank masih dipersulit urusannya.

Dari beberapa permasalahan yang ada dibutuhkan peranan syariah terhadap kemiskinan yang ada. Zakat sebagai syariat dan sistem ekonomi islam yang dapat berhadapan secara langsung dengan kehidupan pedesaan dan sektor pertanian baik yang tradisional maupun modern. Sistem zakat yang ada dilingkungan masyarakat pedesaan dapat dikembangkan berdasarkan faktor berikut ${ }^{29}$ :

a. Faktor zakat yang disalurkan kepada penggarap lahan pertanian bagi para petani miskin dengan kelengkapan alat-alatnya, atau membukakan lahan baru yang masih banyak dan luas didaerah luar jawa

b. Faktor zakat membangun kredit pertanian secara islami yang tidak mengikat dan berbunga

c. Faktor zakat mengatur transmigrasi khusus umat islam untuk membuka tanah pertanian yang baru

${ }^{29}$ Zuhri Saifuddin, Zakat Di Era Reformasi (Tata Kelola Baru)(Semarang: Bima Sejati, 20II).

Volume. I0/No. I/Januari 2022 Al-Iqtishod | 57 
d. Faktor zakat yang dapat membina desa-desa yang berpenghuni muslim yang lebih segar dan nyaman.

Cara mengatasi kemiskinan bisa dengan berbagai strategi. Hal yang harus dilakukan sejak awal ialah mengatasi kemiskinan yang melilit masyarakat sekitar adalah dengan cara mewujudkan tatanan ekonomi yang memungkinkan lahirnya sistem distribusi yang adil, mendorong lahirnya kepedulian dari orang yang mampu (aghniya) terhadap kaum fakir, miskin, dhuafa dan mustadh'afin. Salah satu bentuk kepedulian orang yang mampu adalah kesediaan untuk membayar zakat dan shadaqah ${ }^{30}$.

Strategi pengelolaan zakat yang semuanya berorientasi pada berlipatgandanya pahala muzaki dan untuk meningkatkan kesejahteraan para mustahik dan sistem sentralisasi zakat juga mampu mengentaskan kemiskinan yang ada ${ }^{31}$. Dari berkembangnya zaman distribusi zakat mengalami perubahan, fungsi dan peranan zakat dalam perekonomian juga mengalami penyusutan serta dianggap sebagai ritual ibadah semata, sehingga disfungsi terhadap fungsi zakat sebagai jaminan sosial bahkan sekarang zakat hanya bersifat sebagai kewajiban dan tidak ada rasa empati serta rasa kekeluargaan dan solidaritas untuk sesama. Dalam hal ini terdapat analisa data dalam diagram sebagai berikut :

${ }^{30}$ Atabik, "Peranan Zakat Dalam Pengentasan Kemiskinan."

31 Akhmad Hafi and Bayu Wiguna, "Sentralisasi Pengelolaan Zakat Sebagai Pengentasan Kemiskinan," Ekonomi Dan Bisnis Islam I, no. I (2016): 69-84. 


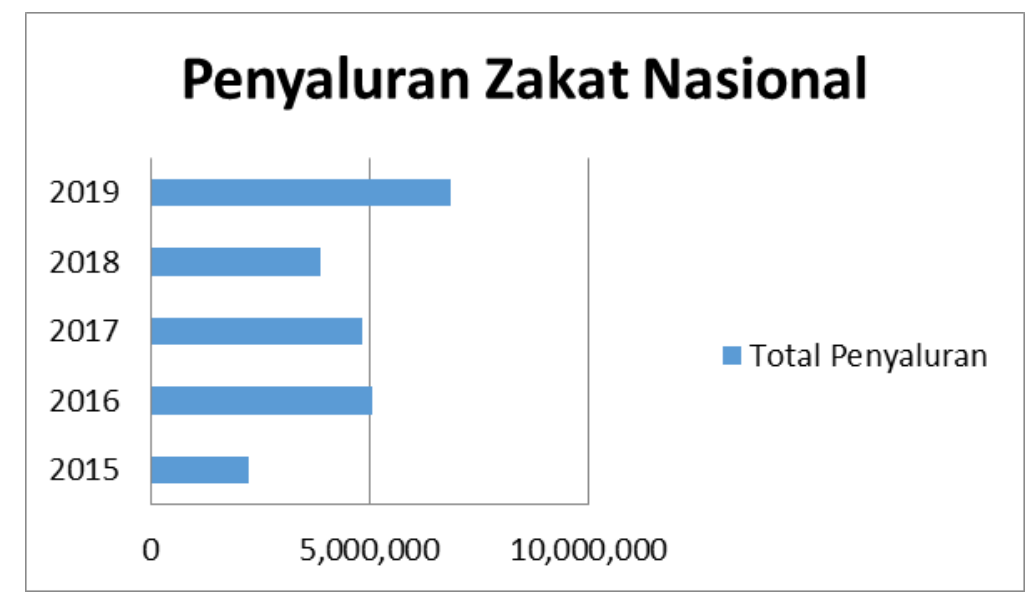

Gambar 3. Penyaluran Zakat Nasional (2015-2019)

Sumber : PPID BAZNAZRI.

Diagram diatas adalam total penyaluran zakat Nasional ditahun 2015 hingga tahun 2019 penyaluran zakat mengalami kenaikan meskipun ditahun 2016 hingga 2018 mengalami penurunan hal tersebut tidak mengganggu peran zakat namun pada tahun 2019 penyaluran zakat secara Nasional mengalami kenaikan yang drastis. Hal tersebut menunjukkan bahwa peran zakat sangat berpengaruh terhadap kemiskinan.

Oleh sebab itu, zakat sangat tepat dalam memperbaiki pola konsumsi, produksi, dan distribusi dengan tujuan mensejahterakan umat. Dikarenakan kejahatan terbesar dari kapitalisme ialah penguasaan serta kepemilikan sumber daya produksi oleh kebanyakan manusia yang diuntungkan dalam segi ekonomi sehingga hal tersebut berimplikasi pada pengabaian mereka terhadap saudara yang kurang mampu secara ekonomi. Dengan demikian, zakat bertujuan untuk meningkatkan produksi, hal ini dilakukan sebab untuk memenuhi tingginya permintaan pada barang.

Al-Qardhawi ${ }^{32}$ memberikan penjelasan bahwa peran zakat dalam mengatasi kemiskinan ialah suatu keniscayaan, meskipun strategi yang dilakukan mengalami banyak kendala. Menurut Al-Qardhawi peran zakat tidak hanya sebatas pada pengentasan kemiskinan, namun juga memiliki tujuan untuk mengatasi permasalahan

32 Yusuf Al-Qardhawi, Spektrum Zakat: Dalam Membangun Ekonomi Kerakyatan, ed. Sari Nurulita (Jakarta: Zikrul Media ilntelektual, 2005).

Volume. I0/No. I/Januari 2022 Al-Iqtishod | 59 
Peran Zakat dalam.....

kemasyarakatan lainnya. Maka peran zakat yang sangat menonjol ialah membantu masyarakat muslim lainnya dan menyatukan hati agar selalu berpegang teguh terhadap islam dan juga membantu setiap permasalahan yang timbul. Jika semua orang kaya atau orang mampu rajin mengeluarkan zakat dan didistribusikan secara adil dan merata niscaya kemiskinan tidak akan terjadi ${ }^{33}$.

\section{E. Simpulan}

Zakat merupakan instrument dalam ekonomi islam yang dapat memberikan pengaruh terhadap tingkah laku seorang muslim dan dapat membangun ekonomi. Indonesia telah mengatur pengelolaan zakat dalam Undang-Undang Pengelolaan Zakat yang dilakukan oleh Badan Amil Zakat Nasional (BAZNAS) dan Lembaga Amil Zakat (LAZ). BAZNAS merupakan suatu badan hukum yang berperan dalam mengelolah zakat dan dibentuk oleh pemerintah yang berkedudukan di Kabupaten atau Kota dan Provinsi. Lembaga-lembaga pengelola zakat harus mampu menjalankan fungsinya yakni sebagai amil zakat. Amil zakat berfungsi sebagai sasaran dalam zakat, dapat merencanakan zakat untuk kedepannya, menghimpun dana zakat dari orang-orang yang wajib membayar zakat, dapat melaksanakan pengelolaan zakat, melakukan pengawasan dalam pengelolaan zakat

Cara mengatasi kemiskinan bisa dengan berbagai strategi. Hal yang harus dilakukan sejak awal ialah mengatasi kemiskinan yang melilit masyarakat sekitar adalah dengan cara mewujudkan tatanan ekonomi yang memungkinkan lahirnya sistem distribusi yang adil, strategi pengelolaan zakat yang semuanya berorientasi pada berlipatgandanya pahala muzaki dan untuk meningkatkan kesejahteraan para mustahik dan sistem sentralisasi zakat juga mampu mengentaskan kemiskinan yang ada. Maka peran zakat yang sangat menonjol ialah membantu masyarakat muslim lainnya dan menyatukan hati agar selalu berpegang teguh terhadap islam dan juga membantu setiap permasalahan yang timbul. Jika semua orang kaya atau orang mampu rajin mengeluarkan zakat dan didistribusikan secara adil dan merata niscaya kemiskinan tidak akan terjadi

${ }^{33}$ Atabik, "Peranan Zakat Dalam Pengentasan Kemiskinan."

60| Al-Iqtishod Volume. IO/No. I/Januari 2022 
Dyah Suryani, Lailatul Fitriani

\section{F. Daftar Pustaka}

Al-Qardawi. Zakat Role in Curing Social and Economic Malaises. Economics of Zakat. Kahf. Jeddah: IRTI-IDB, 2002.

Al-Qardhawi, Yusuf. Spektrum Zakat: Dalam Membangun Ekonomi Kerakyatan. Edited by Sari Nurulita. Jakarta: Zikrul Media iIntelektual, 2005.

Amalia, and Kasyful Mahalli. "Analisis Peran Zakat Dalam Mengurangi Kemiskinan: Studi Kasus Dompet Dhuafa Republika.” Jurnal Ekonomi Dan Keuangan, 2012.

Amalia, Nur. "PERANAN BAZNAS DALAM MENANGGULANGI KEMISKINAN DI KOTA MAKASSAR,” 2020.

Aris, Muslih. "Eksistensi Nilai Al 'Adalah Pada Kebijakan Zakat Di Indonesia.” $A L$ IQTISHOD: Jurnal Pemikiran Dan Penelitian Ekonomi Islam 9, no. I (202I).

Atabik, Ahmad. "Peranan Zakat Dalam Pengentasan Kemiskinan." ZISWAF: Jurnal Zakat Dan Wakaf2, no. 2(2015): 339-6I.

Azis, Abdul, and Ating Sukma. "Strategi Penghimpunan Dana Zakat Lima Lembaga Pengelola Zakat Di Indonesia.” Jumal Syarikah : Jurnal Ekonomi Islam 2, no. I (20I6): I3I-48. https://doi.org/I0.30997/jsei.v2iI.269.

Badan Amil Zakat Nasional. Statistik Zakat Nasional 20I7-20I9, n.d.

Badan pusat statistik. "Profil Kemiskinan Di Indonesia September 2020." www.bps.go.id, 2020.

D, Hafidhuddin. Zakat Dalam Perekonomian Modern. Jakarta: Gema Insani Press, 2002.

Elman, Syaipudin. "Strategi Penyaluran Dana Zakat Baznas Melalui Program

Pemberdayaan Ekonomi." Uin Syarif Hidayatullah, 2015. https://doi.org/I0.I I45/3I32847.3I32886.

Hafi, Akhmad, and Bayu Wiguna. "Sentralisasi Pengelolaan Zakat Sebagai Pengentasan Kemiskinan.” Ekonomi Dan Bisnis Islam I, no. I (2016): 69-84.

Irfan Syauqi Beik. "Analisis Peran Zakat Dalam Mengurangi Kemiskinan: Studi Kasus Dompet Dhuafa Republika.” Pemikiran Dan Gagasan 2, no. January 2009 (2009): 45-53.

"Jurnal Ekbisi Fakultas Syariah.” Jurnal Ekbisi Fakultas Syariah UIN Sunan Kalijaga Yogyakarta 5, no. I (2010).

Kambali, Muhammad, and Fatur Rahman. "Pengaruh Aplikasi Muzakki Corner Terhadap Minat Mayarakat Berzakat" I0, no. 2 (202I): 175-I84.

Nurwati, and Heni Hendrawati. "Zakat Dan Upaya Mengentaskan Kemiskinan." Cakrawala: Jurnal Studi Islam I4, no. I (2019): 40-47. https://doi.org/I0.3I603/cakrawala.vI4iI.2695.

Pratama, Yoghi Citra. "Peran Zakat Dalam Penanggulangan Kemiskinan (Studi Kasus : Program Zakat Produktif Pada Badan Amil Zakat Nasional) [The Role of Zakat in Poverty Alleviation (Case Study: Productive Zakat Program at the National Amil Zakat Board)].” The Journal of Tauhidinomics I, no. I (2015): 93-I04.

Purbasari, Indah. "PENGELOLAAN ZAKAT OLEH BADAN DAN LEMBAGA AMIL ZAKAT DI SURABAYA DAN GRESIK.” Mimbar Hukum 27, no. I (20I5): 68-8I.

Volume. IO/No. I/Januari 2022 Al-Iqtishod | 6 I 
Putri, Rika Rahmadina. "STRATEGI PENYALURAN DANA ZAKAT, INFAQ DAN SHADAQAH (STUDI KASUS BAZNAS KOTA PRABUMULIH).” Adl Islamic Economic 2, no. I (202I).

Qardhawi. Spektrum Zakat Dalam Membangun Ekonomi Kerakyatan. Jakarta: Zikrul Hakim, 2005.

Romdhoni, Abdul Haris. "Zakat Dalam Mendorong Pertumbuhan Ekonomi Dan

Pengentasan Kemiskinan.” Jurnal Ilmiah Ekonomi Islam 3, no. I (2017).

https://doi.org/I0.3I538/adlh.v3iI.403.

Rozalinda. Ekonomi Islam: Teori Dan Aplikasinya Pada Aktivitas Ekonomi. Jakarta:

Rajagrafindo, 2014.

Saifuddin, Zuhri. Zakat Di Era Reformasi (Tata Kelola Baru). Semarang: Bima Sejati, 20 II.

Sugiyono. Metode Penelitian Kuantitatif, Kualitatif, Dan R\&D. Bandung: Alfabeta, 2013.

Sumodiningrat, Gunawan. "Kemiskinan : Teori, Fakta Dan Kebijakan,” 1999.

"Undang-Undang Nomor 23 Tahun 201 I Tentang Pengelolaan Zakat (Lembaran Negara Republik Indonesia Tahun 201 I Nomor II5)," n.d.

Yanjawati, R. Poppy. "Penelitian Studi Kepustakaan (Library Research)." disajikan pada acara "Penyamaan persepsi Penelitian studi kepustakaan" Di lingkungan dosen FKIP Unhas, 2020.

Zed, Mestika. Metode Penelitian Kepustakaan. Jakarta: Yayasan Pustaka Obor Indonesia, 2014. 